\title{
La Escuela Dental de la Universidacl de Concepción
}

(Párrafos que se contienen en la Memoria presentada al Directorio de la Universidad por el Director de esfa Escuela, señor Serapio Carrasco)

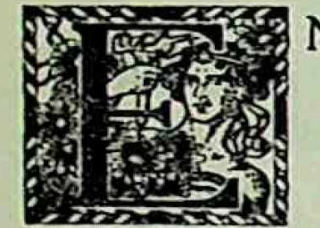

$N$ este quinto año de labor, nos herios empeñado en imprimir a los estudios de Odontología los rumbos netamente cientificos que deben tener. como ciencia que es ésta de tan alta importancia para la salud e higiene social.

Durante los cuatro años anteriores, nos hemos ocupado preferentemente en el régimen interno, en la disciplina, en dotar a las clases, clínicas y laboratorios de los elementos necesarios para hacer más eficiente la enseñanza.

Este anhelo de orientación cientifica ha sido ampliamente realizado en el curso del presente año y hemos podido dar completo desarrollo a los programas de estudio con halagadores resultados.

Nuestro deseo de perfeccionamiento de la Escuela Dental nos ha hecho presentar al H. Consejo de la Universidad un nuevo plan de estudios, en que se consultan cuatro años escolares para los alumnos de Odontología, considerando que en la práctica, el estudio por semestres se hacía más difícil y muchas veces impracticable. En este plan, que empezará a regir el presente año, se consulta. entre otras reformas importantes. la implantación de un período que comprende el primer semestre del segundo año de estudios destinado exclusivamente a la enseñanza completa de los ramos médicos, y, en los ramos de técnica dental, a clases teóricas y trabajos sobre modelo, con el objeto de obtener una mejor atención para los pacientes y un mayor aprovechamiento de los alumnos, destruyéndose así el vacio existente en el antiguo plan, el cual hacia que el alumno ejercitara en la practica conocimientos que no habia adquirido ampliamente ni perfeccionado lo bastante.

Propendiendo a este mismo fin se han agregado nuevas cátedras que no existen en el plan oficial, como ser: Física y Química aplicadas y Electroterapia.

MATRICULA.-Se obtuvo una matricula de ciento catorce alumnos, distribuídos en los diversos cursos como sigue: 35 en el primer año, 40 en el segundo, 23 en el tercero y 16 en el séptimo semestre. La asistencia media anual fué de 105 alumnos.

EXAMENES DE PROMOCIÓN.-Las comisiones designadas por el Honorable Consejo de Instrucción Pública para recibir las pruebas de primera y segunda promoción que, en conformidad al reglamento, deben rendirse al terminar el primero y último curso, cumplió su cometido el día 22 de Diciembre, y fueron aprobados 20 alumnos entre 29 del primer año y los 8 alumnos del $7 .^{\circ}$ semestre que se presentaron a examen. 
PRQFESIONALES.-Del primer curso de esta Escuela. tenemos ya 8 dentistas titulados que ejercen con brillo la profesión, y algunos de los cuales pertenecen al personal docente de nuestra Escuela. Uno de ellos, enviado por la Universidad, perfecciona en Europa métodos de investigación y laboratorio, con el objeto de aportar sus conocimientos a la Escuela.

CLÍNICAS PÚBLICAS. - La confianza del público respecto de los servicios de las Clínicas de la Escuela va en aumento. y es asi como en número de 6.000 enfermos fueron atendidos durante el año último, distribuídos en la forma siguiente: Clínica de Cirugía Oral (extracciones y enfermedades de la boca): 4,400: Clinica de Operatoria: 900 enfermos, con un total de 4,040, de las cuales corresponden: trabajos en oro 1,450; silicatos y poreelanas. 647 y amalgamas 1.943. Clínica de Ortodoncia, Puentes y Coronas: 400 enfermos, de los cuales corresponden Coronas 489 y Puentes 42 . Clinica de Prótesis: 300 enfermos. de los cuales corresponden: 232 placas; 26 placas Bonwill y 42 composturas de placas.

TESORERIA.-Los honorarios que la Escuela percibió por estos servicios ascendieron a la suma total de $\$ 61.524 .19$. Se reparten en la proporción siguiente: Clínica de Operatoria: \$ 38.985.50; Clinica de Ortodoncia, Coronas y Puentes: \$11,992: Clinica de Prótesis: \$ 8.177, y Clinica de Cirugia \$ 2.369.69.

Con este dinero, la Escuela mantiene el funcionamiento de las diferentes Clinicas prácticas y sus servicios, pabellón de Anatomía, agua, luz. gas, aseo.

Aun más, el año que termina, la Dirección de la Escuela tuvo la satisfacción de hacer ingresar a Tesorería la suma de $\$ 16,000$. valor del remanente de sus entradas.

MATERIAL DE ENSEÑANZA.-Con los fondos consultados para la adquisición de material de enseñanza, se ha podido aumentar en forma considerable la dotación existente, y contamos, a la fecha. con sillones suficientes para el trabajo de 80 alumnos en las Clinicas, con un Laboratorio y anexos para trabajos prácticos de técnica dental y con parte de los elementos necesarios para las clases experimentales de Fisiología y Bacteriología, que esperamos sea completado en el presente año. La instalación de Rayos X ha sido sustituida por otra consultada para el uso dental y de moderno sistema.

Estimamos que no llenariamos debidamente nuestro propósito. si antes de terminar la presente Memoria, no manifestáramos nuestro reconocimtento hacia el H. Consejo Directivo por las facilidades que en todo momento ha encontrado de su parte la Dirección de esta Escuela y por la atención con que han sido acogidos sus esfuerzos por colocarla al nivel de los más modernos establecimientos de su clase. Es asi como podemos tener la seguridad de ver comenzar en breve plazo la construcción de un edificio destinado especialmente al funcionamiento de la Escuela Dental, con lo cual quedarán salvados definitivamente los pocos obstáculos y deficiencias que hoy se presentan para el funcionamiento y desarrollo de esta Escuela Universitaria. 